\title{
DUAL ATTRIBUTION IN THE CONTEXT OF MILITARY OPERATIONS
}

\author{
Tom Dannenbaum \\ Lecturer in Human Rights \\ University College London \\ Gower Street, London WC1E 6BT, United Kingdom \\ k.dannenbaum@ucl.ac.uk
}

\begin{abstract}
:
This article considers the state of the doctrine on dual attribution in military operations. The rapidly expanding jurisprudence on cooperative military ventures has yet to coalesce around a single normative framework. The role of the DARIO and DARSIWA in that realm has been decidedly mixed, perhaps predictably given the inconsistency between the two codes. The most hopeful developments have come in the Netherlands, with the elaboration of a bifocal, preventive interpretation of DARIO article 7. However, whether that framework will resonate elsewhere is uncertain. Thus far, the concept of dual attribution itself has played an odd role. It has been affirmed repeatedly in theory, but the primary value of its theoretical possibility has been in empowering courts to hear cases they might otherwise have avoided, while failing actually to attribute conduct to two or more entities.
\end{abstract}

\section{Keywords:}

dual attribution, shared responsibility, peacekeeping, cooperative military enterprise 


\section{A. Introduction}

The vision of article 43 of the United Nations (UN) Charter notwithstanding, international security is viewed by contemporary international law as a field in which states act as unitary actors, exercising self-help, and coordinating only loosely through military alliances. This is an anachronism. Faced with threats that defy the state system, transcend borders, and, in extreme cases, trigger humanitarian imperatives to act, states have turned increasingly to institutionally and operationally thick cooperative military enterprises (CMEs) to further their security objectives.

These ventures are diverse in form and objective. They include ad hoc coalitions, ${ }^{1}$ international-organization-led military deployments, ${ }^{2}$ peacekeeping operations, ${ }^{3}$ multinational occupation forces (authorized or unauthorized), ${ }^{4}$ and merged military operations deployed alongside international administrative missions. ${ }^{5}$

The rise of thick multilateralism should be welcomed. In the face of severe transnational challenges, robust international security cooperation is vital to pursuing peace, security, and human rights. ${ }^{6}$ Indeed, in the absence of centralized enforcement, cooperation is vital to the very rule of international law. ${ }^{7}$ However, in a legal regime premised on independent state responsibility, cooperation poses a doctrinal challenge when these ventures go off the rails. Put

\footnotetext{
${ }^{1}$ For example: Steve Schifferes, 'US Names Coalition of the Willing,' BBC News (18 March 2003).

${ }^{2}$ Consider: UN forces (S.C. Res 2098 (S/RES/2098) 28 March, 2013), UN-authorized NATO forces (S.C. Res. 1386 (S/RES/2098) 20 December 2001), other NATO forces (UK Ministry of Defence, Press Release: 'International partners sign Joint Expeditionary Force Agreement,' 5 September 2014), and EU forces (Aurel Sari and Ramses A. Wessel, 'International Responsibility for EU Military Operations' in Bart Van Vooren, Steven Blockmans, and Jan Wouters (eds.) The EU's Role in Global Governance (Oxford, Oxford University Press 2013) pp. 126-144).

${ }^{3}$ Various regional international organizations have joined the UN in performing this role. S.C. Res 1671, (S/RES/1671), 25 April, 2006; S.C. Res 2085, (S/RES/2085) 20 December 2012; Council of the European Union, 'Council Conclusions on the Central African Republic' 20 January 2014.

${ }^{4}$ The Multinational Force that occupied Iraq starting in 2003 began as a state-led CME lacking UN authorization, but was subsequently authorized. Al-Jedda v. United Kingdom, 7 July 2011, European Court of Human Rights, no. 27021/08, paras. 17-19, 26-35.

${ }_{6}^{5}$ S.C. Res 1244 (S/RES/1244) 10 June 1999.

${ }^{6}$ The presence of peacekeepers, for example, can reduce the risks of renewed conflict, conflict spillover, and atrocity. Michael W. Doyle and Nicholas Sambanis, 'International peacebuilding,' (2000) American Politcal Science Review pp. 779-801; Kyle Beardsley, 'Peacekeeping and the Contagion of Armed Conflict,' (2011) 73 Journal of Politics 1051-1064 (2011); Erik Melander, 'Selected To Go Where Murderers Lurk?'m (2009) 26 Conflict Management and Peace Science pp. 389-406; Virginia Page Fortna, 'Does peacekeeping keep peace?', (2004) 48 International Studies Quarterly pp. 269-292.

${ }^{7}$ Oona A. Hathaway and Scott Shapiro, 'Outcasting,' (2011) 121 Yale Law Journal 252-349; International Law Commission, 'Draft Articles on Responsibility of States for Internationally Wrongful Acts, with Commentaries' in Yearbook of the International Law Commission (A/CN.4/SER.A/2001/Add.1) (2001) ['DARSIWA with Commentaries'] arts 40-41.
} 
crudely: whose wrong is it when a CME violates international law?

The question is difficult precisely because what distinguishes CMEs is that they are governed by merged and redistributed systems of authorization, strategic leadership, operational control, command, and discipline. Troop contributing states and one or more organizations or lead states each take on some fraction of the functions that would ordinarily be held by a single authority. For example, on France's telling the North Atlantic Treaty Organization (NATO) was responsible for the 'direction' of the UN-authorized force in Kosovo (KFOR) and the UN was responsible for 'control' of it, while troop contributors retained disciplinary authority, criminal jurisdiction, troop appointment and promotion authority, and training responsibilities. ${ }^{8}$ The allocation of these functions varies considerably across ventures (and even within the same venture over time). Sometimes even a single function is shared by two or more parties, as exemplified by the UN-NATO 'dual-key' system in Bosnia. ${ }^{9}$

CMEs are hardly the only form of shared conduct challenging the model of independent responsibility. ${ }^{10}$ However, they are particularly prominent in the emergent jurisprudence. First, CMEs are the most common ventures in which states and international organizations merge systems of decision-making and action. ${ }^{11}$ Second, courts have become increasingly receptive to litigation on military operations, rejecting the notion that international humanitarian law (IHL) simply displaces (the more commonly justiciable) international human rights law (IHRL) in times of war, and recognizing a growing sphere of state human rights duties abroad. ${ }^{2}$ Third,

\footnotetext{
${ }^{8}$ Legality of the Use of Force (Federal Republic of Yugoslavia v. France), 15 December 2004, International Court of Justice, Preliminary Objections, ICJ Reports 575, para. 46.

${ }^{9}$ S.C. Res. 836 (S/RES/836) 4 June 1993, para. 10.

${ }^{10}$ André Nollkaemper and Dov Jacobs, 'Shared Responsibility in International Law,' (2013) 34 Michigan Journal of International Law pp. 359-438; Tom Dannenbaum, 'Public Power and Preventive Responsibility', in André Nollkaemper \& Dov Jacobs, Distribution of Responsibilities in International Law (Cambridge, Cambridge University Press, 2015) pp. xx-xx.

${ }^{11}$ Ibid., p.xx. Similar issues arise in collective border enforcement and transnational policing but CMEs are the most common of such ventures.

${ }^{12}$ Dealing with IHL through the lens of IHRL (in various ways), see, for example, Hassan v. United Kingdom, 16 September 2014, European Court of Human Rights, no. 29750/09, paras. 99-107; Mohamed v. Secretary of State for Defence, [2015] EWCA Civ 843, paras. 105-106, 164-253; Legality of the Threat or Use of Nuclear Weapons, 8 July 1996, International Court of Justice, I.C.J. Reports 226, p.240; Legal Consequences of the Construction of a Wall in the Occupied Palestinian Territory, 9 July 2004, International Court of Justice Advisory Opinion, I.C.J. Reports 136, p.178; Bámaca Velásquez v. Guatemala, 25 November 2000, Inter-American Court of Human Rights (ser. C) No. 70, p.79. The issue of extraterritorial jurisdiction has been especially fraught at the European Court of Human Rights. Setting a notoriously high threshold, see Banković v. Belgium and others, 12 December 2001, European Court of Human Rights, no. 52207/99, paras. 54-82. Lowering that threshold, see, inter alia, Al-Skeini and others v. United Kingdom, 7 July 2011, European Court of Human Rights, no. 55721/07, paras. 132-150; Hassan
} 
given the inherently threatening nature of military action to human rights and ongoing uncertainty regarding the interaction between IHL and IHRL, CMEs inevitably generate numerous plausible legal claims. ${ }^{13}$

This article considers the jurisprudence that has emerged as a result of these factors. Part B examines the International Law Commission's (ILC) thin framework of CME responsibility. Part $\mathrm{C}$ evaluates the case law on CME attribution and its recent trajectory. Part D identifies key features of where the law stands today and poses questions regarding the future of the doctrine in this domain.

\section{B. The ILC Framework}

The ILC's work on attribution was articulated in its final form in several provisions of the Draft Articles on Responsibility of States for Internationally Wrongful Acts (DARSIWA) (2001) and the Draft Articles on the Responsibility of International Organizations (DARIO) (2011). ${ }^{14}$ Neither draft code looks set for translation into a binding treaty, but both have the potential to provide the focal points around which custom can develop, and at least some provisions were rooted in pre-existing custom.

Under both codes, all official acts and omissions of state or organization organs or agents are attributable to the state or organization, even if that conduct is ultra vires. ${ }^{15}$ Cooperation between organs or agents - as occurs in the context of detainee transfers - does not alter that foundational attributive link. ${ }^{16}$ One state or organization might be held responsible for its organ having assisted the wrongful conduct of another state in such a scenario, but it would be attributed only with the assistance, not with the primary wrong. ${ }^{17}$ This simple model breaks down when the provision of troops, authorization of the venture, and participation in its strategic

supra note 12, paras. 75-78; Jaloud v. Netherlands, 20 November 2014, European Court of Human Rights, no. 47708/08, paras 143-153.

${ }^{13}$ This is most obviously the case for rights associated with detention and killing.

${ }^{14}$ International Law Commission, 'Draft Articles on the Responsibility of International Organizations,' Report on the Work of its Sixty-Third session, (GAOR 66th Session, sup. No. 10) (A/66/10) (2011) ["DARIO with Commentaries"]; DARSIWA with Commentaries, supra note 7.

${ }^{15}$ DARIO with Commentaries supra note 14, arts 6, 8; DARSIWA with Commentaries, supra note 7, arts 4, 7.

16 This reflects a deep presumption of independent (and not shared) responsibility. See: DARSIWA with Commentaries, supra note 7, p.64; Nollkaemper and Jacobs, supra note 10. On detainee transfer: Soering v. United Kingdom, 7 July 1981, European Court of Human Rights, no. 14038/88; Alzery v. Sweden, 10 November 2006 Human Rights Committee, CCPR/C/88/D/1416/2005.

17 See sources cited supra note 16; DARIO with Commentaries, supra note 14, art. 14; DARSIWA with Commentaries, supra note 7, p.16. 
or operational leadership is distributed among a number of states or organizations. Isolating which conduct is whose in that scenario requires a special rule.

\section{CMEs led by International Organizations}

The provision most commonly invoked to perform that role is DARIO article 7, which provides that the conduct of state (or international organization) organs placed "at the disposal" of an international organization is to be attributed to the latter if it exercises "effective control" over the conduct. ${ }^{18}$ This provision can be interpreted in at least two ways. The first presumes a default attribution that is rebutted when the lead organization controls the conduct; the second presumes no default attribution, but examines each enterprise participant's control over the impugned conduct.

The former has obvious textual appeal. Read in isolation from its Commentary or purpose, DARIO article 7 appears to presume a default attribution to the troop contributor (pursuant to DARSIWA article 4 or DARIO article 6) up to the point that the recipient organization controls the impugned conduct. ${ }^{19}$ Transposing the International Court of Justice (ICJ) interpretation of 'effective control' from the context of attributing non-state actor conduct to states, that would mean attribution to the troop contributor unless the recipient "directed or enforced the perpetration of [the wrongful] acts." 20

This would either preclude dual attribution, on the assumption that the recipient's effective control would displace the ordinary attributive links recognized in DARSIWA article 4 and DARIO article 6, or it would provide for dual attribution whenever the recipient organization exercises effective control, on the assumption that the ordinary attributive links would be

\footnotetext{
${ }^{18}$ DARIO with Commentaries, supra note 14, art. 7.

19 The Dutch Procurator General and the ECtHR have hinted at this interpretation, but each equivocated by emphasizing the contributor's control. André Nollkaemper, 'Procurator General of the Dutch Supreme Court Concludes to Reject Appeal against Srebrenica Judgment,' SHARES Blog (3 May 2013); Al-Jedda, supra note 4, paras. 80-86. See also Kristen E. Boon, 'Are Control Tests Fit for the Future?,' (2014) 15 Melbourne Journal of International Law 15, pp.1-48, p.24.

${ }^{20}$ Military and Paramilitary Activities in and against Nicaragua (Nicaragua v. US), 27 June 1986, International Court of Justice, I.C.J. Reports 14, para. 115; Application of the Convention on the Prevention and Punishment of the Crime of Genocide (Bosnia \& Herzegovina v. Serbia \& Montenegro), 26 February, 2007, International Court of Justice, I.C.J. Reports 43, paras. 397-401; Armed Activities on the Territory of the Congo (DRC v. Uganda), 19 December 2005, International Court of Justice, I.C.J. Reports 168, paras. 146-147. Translating something like this to CMEs, see Marko Milanovic and Tatjana Papic, 'As Bad as it Gets,' (2009) 58 International and Comparative Law Quarterly pp. 267-296, p. 282.
} 
unaffected by that control. ${ }^{21}$ Neither of these radically opposing implications is plausible.

The ILC Commentary and the emerging case law militate instead in favor of applying the effective control analysis not just to the recipient organization, but also to the troop contributor. ${ }^{22}$ Rather than starting with a default attribution, this demands a bifocal, conduct-specific analysis all the way down. When the recipient international organization exercises exclusive effective control over the conduct, the conduct is attributed exclusively to that organization. When the sending state or international organization exercises exclusive effective control, the conduct is attributed exclusively to that entity, pursuant to DARSIWA article 4 or DARIO article 6 , read in conjunction with the text of and commentary to DARIO article $7 .{ }^{23}$ However, attribution to one party does not preclude attribution to another, and when two parties exercise effective control over the conduct, dual attribution is appropriate. ${ }^{24}$ The key question for dual attribution, then, is how broadly to interpret "effective control."

The Commentary states explicitly that 'effective control' in this context plays a "different role" from 'effective control' in the ICJ jurisprudence on attributing non-state actor conduct to states. ${ }^{25}$ In a CME, the question is to which of the participating states or IOs the conduct is to be attributed, whereas in the non-state actor context, the question is whether the conduct is to be attributed to the state at all. ${ }^{26}$ Nonetheless, "effective control' has an "essential ambiguity" that can only be resolved as the standard is applied in practice. ${ }^{27}$ Before turning to courts' efforts in that regard, it is worth considering briefly the ILC's approach to state-led CMEs.

\section{CMEs led by States}

Normatively, there is no reason why attribution should differ when a CME is headed by a state, rather than an international organization. However, in the case of organs "placed at the disposal" of a state, DARSIWA article 6 attributes conduct to that state when the seconded organ

\footnotetext{
${ }^{21}$ Cf. Jordan J. Paust, 'The U.N. Is Bound By Human Rights,' (2010) 51 Harvard International Law Journal Online pp.1-12, p.8.

${ }^{22}$ Tom Dannenbaum, 'Killings at Srebrenica, Effective Control, and the Power to Prevent Unlawful Conduct,' (2012) 61 International and Comparative Law Quarterly pp.713-728, pp. 720-1.

${ }^{23}$ DARIO with Commentaries, supra note 14, p.87.

${ }^{24}$ On the first point, see ibid. p.81.

${ }^{25}$ DARIO with Commentaries, supra note 14, p.86.

${ }^{26} \mathrm{Id}$.

${ }^{27}$ James Crawford, State Responsibility: The General Part (Cambridge, Cambridge University Press, 2013) p. 205 fn. 216
} 
exercises "elements of the [recipient's] governmental authority." 28 In theory, "governmental authority" could be exercised with no recipient control over the impugned conduct; conversely, a high level of recipient control over conduct is compatible with a lack of governmental authority. $^{29}$

Despite its different trigger criterion, DARSIWA article 6 offers two lines of interpretation parallel to those applicable to DARIO article 7. On a plain text reading, an organ's conduct seems to be that of the sending state until it exercises the governmental authority of the recipient, at which point attribution switches to the latter. The Commentary, on the other hand, asks whether the organ "remain[s] under the authority of the sending state," "under the authority" of the receiving state, or, alternatively, whether it is "a joint organ of several States," or acts on their "joint instructions." 30 At the crux of the matter, it continues, "is the establishment of a functional link" between the organ and "the structure of authority" of the relevant state. ${ }^{31}$

The latter test shares key features with the Commentary-inspired, bifocal interpretation of DARIO article 7's effective control test. Both reject a presumptive institutional line of attribution for enterprise conduct, starting instead from the premise that two or more CME participants (at least the contributor and the recipient) have a formal institutional link to each CME troop contingent, and holding that the attributive significance of that formal link is contingent on the distribution of levers of conduct-relevant control (DARIO article 7) or authority (DARSIWA article 6) among the formally linked participants. ${ }^{32}$ This still leaves the different DARIO and DARSIWA trigger criteria, but that might be narrowed by interpreting "functional link" to mean any link relevant to the state's capacity to control the impugned conduct.

Alternatively, a similar harmonization of standards may be feasible through the application of DARSIWA article 8, which attributes conduct when performed "on the instructions of, or under the direction or control of" the relevant state. ${ }^{33}$ The language of article 8 is deliberately flexible. According to the Commentary, "it is a matter for appreciation in each case whether

\footnotetext{
${ }^{28}$ DARSIWA with Commentaries, supra note 7 , art 6.

${ }^{29}$ The indicator that the organ is indeed at the "disposal" of the recipient is that the organ must generally be subject to the recipient's direction, rather than subject to its home state's instruction, but this is seemingly a test of institutional structure, not specific conduct. DARSIWA with Commentaries, supra note 7, p.44; ibid p.44, fn.130.

${ }^{30}$ DARSIWA with Commentaries, supra note 7, p.44.

${ }^{31} \mathrm{Id}$.

${ }^{32}$ Dannenbaum, 'Public Power,' supra note 10, p. XX.

${ }^{33}$ DARSIWA with Commentaries, supra note 7, art. 8.
} 
particular conduct was or was not carried out under the control of a State, to such an extent that the conduct controlled should be attributed to it."34 This flexibility allows an interpretation of DARSIWA article 8 that would mimic DARIO article 7 in CME scenarios, while maintaining a higher DARSIWA article 8 control test for the attribution of non-state actor conduct. ${ }^{35}$

Whether or not article 6 , article 8 , or some combination is the proper frame for a state-led CME is open to debate. ${ }^{36}$ The key point here is that they are both textually divergent from the DARIO model, and yet both sufficiently flexible to overcome that divergence, thereby achieving a harmonization that would have the virtue of realizing normative coherence across the draft codes.

\section{An Emergent Case Law Lacking Normative Unity}

DARSIWA and DARIO flexibility here reflects the minimal prior practice on the issue of dual attribution in shared military ventures. A consequence is that much doctrinal work has been pushed downstream to state practice and adjudication. This Part explores the latter, looking first at various early forms of hostility to dual attribution, then examining the ways in which courts have opened to the idea, and finally identifying enduring uncertainties.

\section{An Early Problem}

One of the earliest relevant cases predates both ILC codes. At its core was a claim against the UK before the European Commission on Human Rights (ECmHR) regarding Rudolf Heß's detention in Berlin-Spandau prison. ${ }^{37}$ The prison had been established by the Allied Kommandatura (the governing body for post-World War II Berlin) to house Nazi war criminals, and was administered by the UK, the US, the USSR, and France under a system of overall unanimity, with operations performed by representatives of one state at a time on a three-month rotation. Only the UK was subject to the ECmHR's jurisdiction. In declining to consider the merits, the Commission explained that responsibility for the detention was "exercised on a Four Power basis" with the UK only "a partner in the joint responsibility which it shares with the three

\footnotetext{
${ }^{34}$ Id. p.48. See also Boon, supra note 19, p.18.

${ }^{35}$ Cf. Ibid. p.26; Aurel Sari, 'Untangling Extra-territorial Jurisdiction from International Responsibility in Jaloud v. Netherlands,' (2014) 53 Military Law and Law of War Review pp.287-318, Part V.2.

${ }^{36}$ A key issue is whether CME military operations abroad ever count as exercises of "governmental authority" (per article 6). The Commentary gives no guidance on this, except to say that "mutual defense" arrangements do not count. DARSIWA with Commentaries, supra note 7, p.44.

${ }^{37}$ Hess v. United Kingdom, 28 May 1975, European Commission of Human Rights, no. 6231/73.
} 
other Powers.",38

The holding can be read in one of two ways. First, the Commission's premise may have been that attribution to the UK would have entailed attribution to the other three states as indispensable third parties on whose obligations it lacked the authority to rule. ${ }^{39}$ This highlights the potential of dual attribution to pose an obstacle to litigation, given the frequency with which no court or interpretive authority would have jurisdiction over all relevant participants. As discussed in Part D, recent jurisprudence has moved in the opposite direction, with dual attribution a litigation enabler.

If the first interpretation of Hess spotlights the way that dual attribution might obstruct accountability, the second is hostile to the very idea of dual attribution. On this interpretation, the ECmHR meant that only the Kommandatura itself, and not its state participants, could be attributed with official prison conduct. Hinting at this, the Commission observed, "joint authority cannot be divided into four separate jurisdictions. ${ }^{, 40}$ The implications of such a rule are even more severe. It would allow states or international organizations to create CMEs that are themselves not subject to international law or to the jurisdiction of any court, and yet that are the only entities attributed with enterprise conduct.

Whichever way one interprets Hess, its implications for CME accountability are not promising. Either multiple attribution to enterprise participants blocks accountability, or attribution to CME participants ought to be rejected altogether. As discussed below, each of these has been discarded over time. The second in particular would be in significant tension with the DARSIWA and DARIO, which hold that joint organs are to be attributed to all relevant states and organizations, and that states may not use international organizations to circumvent their obligations. $^{41}$

\section{Early Hostility to Dual Attribution}

Nonetheless, initially at least, the drafting of the DARIO and DARSIWA did not trigger a

\footnotetext{
${ }^{38} I d$.

${ }^{39}$ Cf. Monetary Gold Removed from Rome in 1943 (Italy v. France, United Kingdom and United States of America), 15 June 1954, International Court of Justice, I.C.J. Reports 19, pp. 32-33; Case Concerning East Timor (Portugal v. Australia), 30 June 1995, International Court of Justice, I.C.J. Reports 90, para 28. But see Certain Phosphate Lands in Nauru (Nauru v. Australia), 26 June 1992, International Court of Justice, Preliminary Objections, I.C.J. Reports 240, para. 55.

${ }^{40}$ Hess, supra note 37.

${ }^{41}$ DARIO with Commentaries, supra note 14, pp. 87-88, 110, art. 61.
} 
judicial opening to dual attribution. Moreover, the single attribution that the courts favored at that stage-presumptive attribution to the lead organization-proved an obstacle to accountability due to courts' lack of jurisdiction over international organizations.

The landmark judgment in this respect was the 2007 European Court of Human Rights (ECtHR) ruling in Behrami, which denied claims against states involved in the UN-authorized NATO force in Kosovo (KFOR). ${ }^{42}$ Despite referencing what would become DARIO article 7 and finding that NATO held "effective command of the relevant operational matters," the Court attributed KFOR acts and omissions exclusively to the UN because it had "ultimate authority and control" over the force in light of the facts that the Security Council authorized the force, delegated operational control to NATO within broad limits, and received regular reports from the field. $^{43}$

Attribution of the conduct to the UN on these grounds disposed of any question of attribution to the troop contributors, implying that dual attribution would obtain on this model only if a group of states stood collectively in the position of the UN vis-à-vis KFOR. ${ }^{44}$ Attribution would have been shifted to a troop contributing state only if that state were to have intervened disruptively to nullify NATO control and UN ultimate authority. ${ }^{45}$ In the absence of any court with jurisdiction over the UN, the accountability deficit was conspicuous. ${ }^{46}$

As explained below, Behrami diverged radically from both of the alternative DARIO interpretations discussed in Part B. Nonetheless, it endured in the short term, and continues to influence attribution decisions today. ${ }^{47}$

A year after Behrami, the District Court in The Hague advanced an alternative test in H.N.

\footnotetext{
42 Behrami v. France and Saramati v. France, Germany and Norway, 2 May 2007, European Court of Human Rights, nos. $71412 / 01 \& 78166 / 01$.

${ }^{43}$ Ibid. paras. 132-41.

${ }^{44}$ Yugoslavia argued that the North Atlantic Council waged the 1999 war against it "as a joint enterprise," such that all member states were "attributable jointly and severally" with the command structure that they had created,. Legality of Use of Force (Serbia and Montenegro v. United Kingdom) (Oral Proceedings) [Public Sitting 12 May 1999] Transcript, CR 1999/25, 16.

${ }^{45}$ Behrami, supra note 42, paras. 138-139.

${ }^{46}$ Cf. Tom Dannenbaum, 'Translating the Standard of Effective Control into a System of Effective Accountability,' (2010) 51 Harvard International Law Journal pp.113-192, pp. 121-129.

${ }^{47}$ Following Behrami: Kasumaj v. Greece, 5 July 2007 European Court of Human Rights, no. 6974/05; Gajić v. Germany, 28 August 2007, European Court of Human Rights, no. 31446/02. On its impact recently, see Part C.4 infra.
} 
v. Netherlands. ${ }^{48}$ Its crux was the transfer by the Dutch battalion (Dutchbat) of the UN peacekeeping force in Bosnia and Herzegovina of the claimants' family members from the battalion's Potočari compound to the Bosnian Serb Army during the latter's genocide at Srebrenica. The Court attributed the transfer to the UN due to its 'operational command and control' over the enterprise, holding that the Netherlands would have been attributed only if it had 'cut across' the UN chain of command by directing Dutchbat 'to ignore' or 'go against' UN orders. ${ }^{49}$ Even 'parallel instructions' would not have warranted attribution to the Netherlands. ${ }^{50}$ Although reversed on appeal, H.N. articulates the standard claimed by the UN and troop contributors in most peacekeeping missions. ${ }^{51}$

Both H.N. and Behrami depart from the DARIO framework (on either interpretation of the latter). The textualist interpretation of DARIO article 7, like both judgments, is built on a presumption that all enterprise conduct will be attributed to a specific actor. However, while the DARIO presumption attributes all conduct to the contributor state (unless the lead organization directs the conduct), Behrami and H.N. adopt the diametrically opposed position, attributing all conduct to the lead organization (unless a contributor overrides its command and directs the conduct). By eschewing either enterprise-level presumption in favor of a conduct-specific control analysis, the bifocal interpretation of DARIO article 7 conflicts even more fundamentally with both judgments. ${ }^{52}$

The most plausible reconciliation between H.N. or Behrami and the DARIO would be to define the CME in each case as an organ of the UN, covered by DARIO article 6, with the contributor state imputed with conduct only when it usurps control, per DARSIWA article $8 .^{53}$ However, neither court suggested that it viewed things in that light. Moreover, if state troop contingents sent to act under UN operational control are not state organs "placed at the disposal" of an international organization, it is difficult to imagine what is covered by article 7 .

H.N. and Behrami differ on what counts as leading the enterprise in a way that underpins

\footnotetext{
48 Rechtbank's-Gravenhage, HN v. Netherlands (Ministry of Defense and Ministry of Foreign Affairs), Judgment, LJN: BF0181/265615 (10 September 2008) ('H.N. District Court Judgment').

${ }^{49}$ H.N. District Court Judgment, supra note 48, para. 4.14.1.

${ }^{50}$ Ibid.

${ }^{51}$ DARIO with Commentaries, supra note 14, p.88; Secretary-General, 'Administrative and Budgetary Aspects of the Financing of the United Nations Peacekeeping Operations,' (A/51/389) 20 September 1996, paras. 7-8; Dannenbaum, 'Translating,' supra note 46, p.153.

${ }^{52}$ Dannenbaum, 'Public Power,' supra note 10, p.xx.

${ }^{53}$ On the CME as the organ of the recipient IO, see Sari and Wessel, supra note 2, p.132.
} 
the attributive presumption. Applied to the Behrami facts, the H.N. rule would have attributed KFOR's actions to NATO, and not to the UN. But what they share is the basic premise that leadership of the enterprise (however defined) is presumptively attributive of all enterprise conduct, unless another entity distorts the normal workings of that system. ${ }^{54}$ Moreover, neither allows for dual attribution, unless the lead entity is itself a collective.

If Behrami reflects a normative principle, it seems to be that the entity authorizing the CME should structure the enterprise so that it retains the levers of control necessary to ensure good conduct. ${ }^{55}$ However, this principle misunderstands the agreements that structure CMEs. ${ }^{56}$ All states and organizations that participate in multinational enterprises cede some form of control to one another. Doing so is essential to effective international cooperation of this kind and is vital to the very enforcement of contemporary international law. ${ }^{57}$ The choice for participants (including the authorizing participant) is not between retaining total control and ceding control; it is between ceding control and forgoing collaboration. Given the value of such cooperation, as long as the enterprise is lawful and any instance of enterprise wrongdoing is attributable to at least one state or organization, attribution should reflect the agreement that was reached, not what might have been.

\section{Movement to Bifocal Conduct-Specific Analysis and Dual Attribution}

Behrami and H.N. were the high water marks for both enterprise-level presumptions and hostility to dual attribution. The ECtHR's first steps away from both positions came in Al-Jedda v. $U K$, a 2011 case involving the detention of a terrorist suspect by UK forces operating as part of the UN-authorized Multinational Force (MNF) in Iraq. ${ }^{58}$ The UK argued unsuccessfully that Behrami mandated attributing Al-Jedda's detention to the UN because the Security Council maintained ultimate authority and supervised the force via periodic reporting. ${ }^{59}$

At first seeming to accept the UK's doctrinal premise, the Court distinguished the case

\footnotetext{
${ }^{54}$ Cf. Aurel Sari, 'UN Peacekeeping Operations and Article 7 ARIO,' (2012) 9 International Organizations Law Review pp.77-85, p.83; Sari and Wessel, supra note 2, p.141.

${ }_{55}^{5}$ See, e.g., Danesh Sarooshi, The United Nations and the Development of Collective Security (Oxford, Oxford University Press, 1999) p.164.

${ }^{56}$ Dannenbaum, 'Public Power,' supra note 10, p.xx.

${ }^{57}$ Ibid. p.xx.

${ }_{58}^{58}$ Al-Jedda, supra note 4.

${ }^{59}$ Ibid. para. 64.
} 
from Behrami on factual grounds. ${ }^{60}$ However, it then made two doctrinal shifts that seemed to render the factual distinctions redundant. First, it separated the question of whether MNF conduct was attributable to the UN from the question of whether it was attributable to the UK, raising the possibility (contra Behrami) that both questions could be answered in the affirmative, generating dual attribution. ${ }^{61}$

Second, the Court held that the UN had "neither effective control nor ultimate authority and control" over the detention, whereas the UK did exercise control over the detention, despite external committee review. ${ }^{62}$ Despite its unhelpful equivocation on the applicable rule and its failure to elaborate on what 'effective control' entails, the judgment inched towards the ILC rule and away from the notion that authorizing and periodically supervising the enterprise is sufficient for exclusive attribution with its conduct. ${ }^{63}$

More impressive strides in that direction have been made in the Dutch courts. This began with the reversal of H.N. at the appellate level in Nuhanović v. Netherlands and has continued as the next round of litigation has built on that step forward. ${ }^{64}$

Unlike the ECtHR, the Nuhanovic Court of Appeal structured its entire ruling around DARIO article 7, identifying 'effective control' as the only applicable test. ${ }^{65}$ Equally significantly, the Court interpreted the 'effective control' test in the bifocal form introduced in Part B, determining attribution by "which of both parties has 'effective control' over the relevant conduct." ${ }^{, 66}$ As I argued in an article cited by the Court as a source on effective control, this deviation from the article 7 text was both normatively well-directed and consistent with the ILC's Commentary, which defines "the decisive question" as "who has effective control over the conduct in question" and roots any attribution to the contributing state in "the control that the

\footnotetext{
${ }^{60}$ Ibid. paras. $77-83$.

${ }^{61}$ Ibid. para. 80 .

${ }^{62}$ Ibid. paras. 84-85.

${ }^{63}$ Cf. Munaf v. Geren, 533 US 1, 8 (2008) (reaching a similar conclusion regarding an analogous domestic law issue).

${ }^{64}$ Gerechtshof's-Gravenhage, Nuhanović v Netherlands, Appellate Judgment, LJN: BR 5388 (5 July 2011) ["Nuhanović Appellate Judgment"].

${ }^{6}$ Ibid. para. 5.8 .

${ }^{66} \mathrm{Ibid}$. [emphasis added].
} 
State possesses in the relevant respect." ${ }^{, 67}$

Adopting this bifocal approach has profound implications for the meaning of "effective control." As the ILC notes correctly, ultra vires conduct should no more be left unattributed when it is performed by CMEs than it is in unilateral contexts. ${ }^{68}$ This rules out transposing the ICJ's 'effective control' standard for attributing the conduct of non-state actors, because it will often be the case that no CME participant "directed or enforced the perpetration of [the wrongful] acts." 69 Appreciating this, the Court of Appeal instead defined the 'effective control' test to ask whether "the UN or the State had the power to prevent the conduct," thereby incorporating my core proposal in the aforementioned article. ${ }^{70}$ Since multiple actors can hold preventive power, this move was intrinsically friendly to dual attribution, which the court affirmed explicitly. ${ }^{71}$

The explicit endorsement of a bifocal test, the preventive interpretation of "effective control," and dual attribution were all major shifts from H.N. and Behrami. However, the Court's application of the "power to prevent" focused on a contextual peculiarity, leaving the doctrine's scope ambiguous. After Srebrenica fell, the Dutch government decided to withdraw Dutchbat and, with UN cooperation, began (unusually) to issue orders to the troops additional to those of UN command. ${ }^{72}$ The Court surmised that the Netherlands held preventive effective control, because if it were to have instructed "Dutchbat not to [evict the individuals from Potočari], such an instruction would have been executed."73

Ordinarily, failing to prohibit wrongful conduct is one way of failing to prevent it - it is

\footnotetext{
${ }^{67}$ DARIO with Commentaries, supra note 14, pp. 85, 87. See Nuhanović Appellate Judgment, supra note 64, para 5.8; Dannenbaum, 'Translating,' supra note 46, p.141. For a more detailed analysis of the Commentary, see Dannenbaum, 'Killings at Srebrenica,' supra note 22, pp.721, 724-25.

${ }^{68}$ On the ultra vires acts of international organization organs and state organs, Part B. On the ultra vires acts of CMEs and the reason for attributing ultra vires conduct, see DARIO with Commentaries, supra note 14, pp. 85, 93

${ }^{69}$ The ICJ's approach has returned repeated null results. Nicaragua, supra note 20, para. 116; Bosnian Genocide, supra note 20, paras. 413-5; Armed Activities, supra note 20, para. 160.

${ }^{70}$ Nuhanović Appellate Judgment, supra note 64, para 5.9 [emphasis added]. See DARIO with Commentaries, supra note 14, p.91 fn129; Crawford, supra note 27, p. 206; André Nollkaemper, 'Dual attribution,' (2011) 9 Journal of International Criminal Justice pp.1143-1157, p.1148. For my original articulation, see Dannenbaum, 'Translating,' supra note 46, p.157. Supporting the test more recently, see Noemi Gal-Or \& Cedric Ryngaert, 'From Theory to Practice,' (2012) 13 German Law Journal pp.511-541, p. 529.

${ }^{71}$ Nuhanović Appellate Judgment, supra note 64, para 5.9.

${ }^{72} \mathrm{Ibid}$. paras. 5.10-5.12, 5.18. On the original UN structure, see ibid. para. 5.7.

${ }^{73}$ Ibid. para. 5.18, 5.20, 6.8, 6.20.
} 
simply a passive form of authorization. ${ }^{74}$ However, this basis for attribution to the Netherlands was unfortunate on two levels. First, it obscured the preventive principle's implications for more typical scenarios. Second, the Netherlands' failure to prohibit was not a passive form of authorization in this case. UN command, which retained simultaneous operational control, had ordered Dutchbat to "[t]ake all reasonable measures to protect refugees and civilians in your care" - an order that (according to the Court) Dutchbat contravened when it evicted the claimants' relatives. ${ }^{75}$ In other words, the problem was not that the battalion did not receive a legally binding order to refrain from the wrongful conduct; it was that it disobeyed precisely such an order.

This is crucial. The power to prevent disobedient conduct is not held by those that could have given alternative orders. By its nature, such conduct denies the efficacy of orders as levers of control. ${ }^{76}$ Effective control in that context is held instead by the state(s) or international organization(s) that have the power to generate lawful decision-making and obedience to orders. Like most contributor states in peacekeeping missions, the Netherlands exercised that form of control over Dutchbat in the form of its criminal jurisdiction and its authority to select and train the troops, to structure the battalion hierarchy, and to discipline or dismiss those that breached orders. That was sufficient to attribute the wrongs to the Netherlands, quite apart from its operational role. ${ }^{77}$ Of course, different Dutch orders may have been more effective than the UN order in preventing the eviction, but if that was so, it was surely because the Netherlands held the obedience-generating levers of control, not because it, just like the UN, was in a position to issue orders.

Properly understood, the bifocal, preventive interpretation of 'effective control' inquires of each enterprise participant whether that participant held a sufficient concentration of the levers of control most relevant to preventing the wrongful conduct in question. ${ }^{78}$ As the discussion above indicates, those levers include far more than just the authority to direct. Which of them underpin(s) attribution depends on the conduct.

Despite relying on the Netherlands' power to have issued alternative orders, the Court did

\footnotetext{
${ }^{74}$ See Dannenbaum, 'Translating,' supra note 46, pp.165-170.

${ }^{75}$ Nuhanović Appellate Judgment, supra note 64, paras. 2.16, 6.8.

${ }^{76}$ Dannenbaum, 'Translating,' supra note 46, p.160.

${ }^{77}$ Ibid. p.164. Dannenbaum, 'Public Power,' supra note 10.

${ }^{78}$ Ibid. pp.xx-Xx.
} 
indicate some openness to this alternative framing. Abstractly, it linked the concept of effective control to responsibility for personnel matters, disciplinary authority, and criminal jurisdiction. ${ }^{79}$ Concretely, it noted the attributive "importan[ce]" of Dutchbat's violation of the UN order and the Netherlands' disciplinary authority ${ }^{80}$

The Dutch Supreme Court upheld the Nuhanović judgment, endorsing without qualification the Court of Appeal's attribution analysis and affirming explicitly the possibility of dual attribution. ${ }^{81}$ However, by failing to discuss the preventive aspect of effective control, it left the role and contours of that doctrine uncertain. ${ }^{82}$

The District Court in The Hague has since begun to fill that gap. The Mothers of Srebrenica brought suit against the Netherlands and the UN in a case that covered the same events as Nuhanović, but a much broader range of those killed at Srebrenica. ${ }^{83}$ After delays associated with the separation, dismissal, and appeal of the case against the UN, the District Court only reached the merits of the claims against the Netherlands after Nuhanovic had run its course. ${ }^{84}$ Accepting both the preventive interpretation of effective control and the concept of dual attribution, Mothers of Srebrenica v. Netherlands built on the earlier case. ${ }^{85}$

The Court assessed preventive control by evaluating the particularities of the impugned conduct against the "powers the State still had" and the "powers it had transferred" among operational control, troop selection, control over personnel matters, disciplinary authority, criminal jurisdiction, and the authority to withdraw the battalion. ${ }^{86}$ Alive to the role of many of these levers of control in generating obedience, the Court concluded that when a battalion under exclusive UN operational control acts contrary to UN orders or authorization, that "action is

\footnotetext{
${ }^{79}$ Nuhanović Appellate Judgment, supra note 64, para 5.10

${ }^{80}$ ibid para 5.18. See also Boon, supra note 19, pp.39-40.

${ }^{81}$ Netherlands v. Nuhanović, ECLI:NL:HR:2013:BZ9225, Hoge Raad der Nederlanden (Supreme Court of the Netherlands) 6 September 2013, paras. 3.11.2, 3.11.3, 3.12.2, 3.12.3.

${ }^{82}$ Its silence on preventive control might be considered dismissive. Boon, supra note 19, p.40. However, the Procurator General had rejected explicitly the preventive dimension of its effective control analysis, whereas the Supreme Court (although silent on prevention) endorsed the lower court's decision without qualification or caveat. Nollkaemper, 'Procurator General,' supra note 19.

${ }^{83}$ Rechtbank's-Gravenhage, Mothers of Srebrenica v. Netherlands, Judgment, LJN: 8748 / C/09/295247 (17 July 2014) paras. 4.3, 4.11.

${ }^{84}$ On the earlier litigation against the UN and against the Netherlands for upholding UN immunity, see Mothers of Srebrenica v. Netherlands and UN, Judgment, LJN: BW1999 (2012), upheld in Stichting Mothers of Srebrenica v. Netherlands, 11 June 2013, European Court of Human Rights, no. 65542/12, paras. 135-70.

${ }^{85}$ Mothers of Srebrenica v. Netherlands, supra note 83, paras. 4.33-4.34, 4.44-4.46.

${ }^{86}$ Ibid. paras. 4.36, 4.41, 4.46. Cf. Dannenbaum, 'Translating,' supra note 46, pp.158-164.
} 
attributable to the State supplying the troops because the State [through those levers of control] has a say over the mechanisms underlying said ultra vires actions." 87

On this basis, the Court attributed to the Netherlands all of the Dutchbat conduct that contravened the UN order to protect civilians within the battalion's care. ${ }^{88}$ As I argued both before and after Nuhanović, this is the right application of the preventive interpretation. ${ }^{89}$ In Mothers of Srebrenica, it led the Court to find that the Netherlands violated its right to life obligations to 320 men evicted from Potočari. ${ }^{90}$

In each of these respects, Mothers of Srebrenica built impressively on Nuhanović. There are, however, two dimensions of its analysis relevant to dual attribution that might be questioned. First, the Court left open the possibility that Dutchbat action in contravention of UN orders could also be attributed dually to the UN. ${ }^{91}$ This would be too expansive. Unless the entity with the authority to issue orders also holds key levers of control over obedience generation, it has no effective control over disobedient acts. ${ }^{92}$ Second, in evaluating Dutchbat's alleged direction of approaching refugees into the surrounding woods (prior to the aforementioned UN order), the Court concluded implicitly that actions neither ordered nor banned by the UN were attributable only to the UN. ${ }^{93}$ This is too restrictive. Having failed to narrow the battalion's discretion to lawful acts, the UN was attributable with resulting wrongs, but the Netherlands' control over training, troop-selection, discipline, and contingent structure were also relevant to preventing the contingent from abusing its discretion. ${ }^{94}$ It is not only when troops act ultra vires that a troop

\footnotetext{
${ }^{87}$ Mothers of Srebrenica v. Netherlands, supra note 83, paras 4.57-4.58.

${ }^{88}$ Ibid. Para. 4.89. See also ibid. paras. 4.94-4.95, 4.98, 4.114-4.115. In line with Nuhanović, the Court repeated the theory of dual operational control during the transition period, [Mothers of Srebrenica v. Netherlands, supra note 83, paras $4.80,4.87]$ but, in contrast to Nuhanović, the control-over-obedience theory was given equal prominence and equal impact.

${ }^{89}$ Dannenbaum, 'Killings at Srebrenica,' supra note 22, pp.726-727; Dannenbaum, 'Translating,' supra note 46, pp.158-164. This may be part of "the literature" to which the Court refers without citation. Mothers of Srebrenica v. Netherlands, supra note 83 , para. 4.60.

${ }^{90}$ See $i d$. paras 4.324-4.338. The remaining killings were not deemed to be the consequence of illegal Dutchbat conduct because Dutchbat lacked extraterritorial jurisdiction vis-à-vis refugees outside the compound (ibid. para. 4.160-4.161), the battalion lacked reasonable alternatives (ibid. para. 4.192-4.198, 4.283, 4.290-4.291) or there was no established causal link between its wrongs and refugee deaths. Ibid. paras. 4.201, 4.276-4.278.

91 Ibid.

92 Dannenbaum, 'Translating,' supra note 46, pp.158-164; Dannenbaum, 'Public Power,' supra note 10, p.XX.

${ }^{93}$ Mothers of Srebrenica v. Netherlands, supra note 83, paras 4.104-4.111.

${ }^{94}$ Dannenbaum, 'Translating,' supra note 46, pp.165-170; Dannenbaum, 'Public Power,' supra note 10, p.XX. Cf. Cedric Ryngaert, Srebrenica Continued, (2014) 61 Netherlands International Law Review pp.365-454, pp.367-368 (arguing, correctly in my view, that these actions should have been attributed to the Netherlands, but questioning whether they could have been attributed to the UN).
} 
contributor with these powers is attributable..$^{95}$

Despite these issues, the judgment is the most complete and impressive judicial elaboration of the preventive interpretation to date. If Behrami and H.N. set the high water mark for enterprise-level presumptions and hostility to dual attribution, Mothers of Srebrenica marks the zenith (so far) of the bifocal, conduct-specific approach and its openness to dual attribution.

\section{Jurisprudential Retrenchment?}

Indeed, two recent rulings-Jaloud v. Netherlands and Mohamed v. Secretary of Defence - may indicate that the progress in the Dutch Courts was anomalous and that Al-Jedda was rooted more in a factual peculiarity than in a genuine doctrinal departure from Behrami.

Jaloud addressed the April, 2004 actions of the Dutch contingent in the force operating under the UN-authorized, US- and UK-led Coalition Public Authority (CPA) in Iraq. ${ }^{96}$ The case involved a lethal shooting at a military checkpoint, most likely by a Dutch lieutenant. ${ }^{97}$ The victim's father claimed that the investigation into the killing violated ECHR article 2's procedural requirements. ${ }^{98}$

The Netherlands denied that it could be attributed with the contingent's conduct, noting that the UK was the public authority in the area and that a UK commander exercised operational control over the contingent. ${ }^{99}$ The Netherlands also claimed that merely controlling a checkpoint approached by an individual does not trigger extraterritorial human rights obligations to that individual, because it does not amount to exercising full control over the individual, effective control over territory, or public powers ordinarily exercised by the host. ${ }^{100}$

These two issues - attribution and extraterritorial jurisdiction — are distinct legal questions, and the ECtHR addressed them separately. However, in establishing that the Netherlands had Convention obligations at the checkpoint (a jurisdictional issue, correctly located in the jurisdiction section), the Court emphasized factors pertaining to Dutch control over the contingent (an attribution question). It noted that despite UK operational control, the Netherlands

\footnotetext{
95 Ibid. p.367.

96 Jaloud, supra note 12.

97 The lieutenant fired 28 times, but Iraqi Civil Defense Forces or other Dutch troops may have shot, too. Ibid. paras. $10-16$.

${ }^{98}$ Ibid. paras. 105-108. On the investigation and domestic process see paras. 17-48.

${ }^{99}$ Ibid. paras. 113-115. See also ibid. para. 57.

${ }^{100}$ Ibid. paras. 109-110, 112-114, 116-126.
} 
retained the right to contribute to the formation of "essential policy," the authority to narrow its troops' rules of engagement, and "full command" over its troops (entailing the preventive levers of control identified in Mothers of Srebrenica). ${ }^{101}$ Whether dual attribution to the UK would have been appropriate was left unaddressed.

The designated attribution section was notably less detailed. The Court asserted simply that the Dutch troops were not placed "at the disposal" of any foreign power or "under the exclusive direction or control" of another state. ${ }^{102}$ This is the language of DARSIWA article 6 and an isolated line of its Commentary, but the Court neglected to cite those sources directly or to connect the concepts to the facts. ${ }^{103}$ In this cursory section, the Court also observed that the "complaints derive from alleged acts and omissions of Netherlands military personnel and investigative and judicial authorities."104

Both the attribution analysis in the jurisdiction section and that in the designated attribution section warrant attention. Consider the formal attribution analysis first. The claim against the Netherlands was not that Jaloud's was a wrongful killing, but that it was inadequately investigated. ${ }^{105}$ The Netherlands held exclusive responsibility for such investigations; its Dutch Royal Military Constabulary had "its own line of command" and was "directly answerable to the Minister of Defence." ${ }^{\prime 106}$ In other words, the investigators were not part of the merged CME. As such, the investigative inadequacy (as opposed to the killing itself) was plainly attributable to the Netherlands. ${ }^{107}$ Although the Court is not explicit here, this explains its brevity and the prominence of the investigative and judicial authorities in the designated attribution section.

The jurisdiction section is more interesting and provokes three questions. Given that the impugned conduct was the failure to investigate, why was it necessary to attribute the conduct of the troops involved in the shooting $?^{108}$ Why was this analysis located in the jurisdiction section?

\footnotetext{
${ }^{101}$ Ibid. paras. $57,100,143,146-149$.

102 Ibid. paras. 141.

${ }^{103}$ DARSIWA with Commentaries, supra note 7, pp. 43-44. Identifying applicable law earlier in the judgment, the Court referenced DARSIWA articles 2, 6 and 8. However, it never linked these provisions to the facts or to the substantive reasoning. Jaloud, supra note 12, paras. 95-98.

${ }^{104}$ Ibid. para. 155.

${ }^{105}$ Listing the deficiencies of the investigation, see ibid. paras. 227-228.

${ }^{106}$ Ibid. paras 60-61

${ }^{107}$ Cf. DARSIWA with Commentaries, supra note 7, art 2.

108 The duty to investigate does not hinge on whether state agents performed the killing. Ergi v. Turkey, 28 July 1998, European Court of Human Rights, no. 23818/94, para. 82.
} 
And, what are we to make of it substantively? The answer to the first two questions seems to lie in the following unstated premise: a CME contingent that assumes a certain form of control over potential claimants thereby triggers the extraterritorial ECHR obligations only of those states attributable with the conduct that established the organ's jurisdictional link. ${ }^{109}$ Thus, if the troops at the checkpoint exercised sufficient authority and control vis-à-vis Jaloud to trigger human rights obligations towards him and his next of kin (a jurisdictional question), it matters to which state those troops' conduct was attributable (an attribution question), because that determines which state had the extraterritorial duty to investigate his death. ${ }^{110}$ Whether or not this was the right approach to extraterritoriality is tangential here. The relevant point is that it identifies the examination of the Dutch connection to the troops at the checkpoint as a complete CME attribution analysis that ought to be evaluated as such. ${ }^{111}$

That substantive evaluation is complicated by the Court's failure to explain why "full command" determined the attribution of the conduct at the checkpoint. On one interpretation, the Court's reference to Dutch full command stood alone as a sufficient basis for attribution to the Netherlands. ${ }^{112}$ If that is what the ECtHR meant, the case marked a jurisprudential retreat. Without some criterion of the relevance of full command to the occurrence of the impugned conduct, such a rule would discard conduct-specific analysis altogether on the troop contributor side. $^{113}$

This would repeat the normative error at the heart of H.N. and Behrami. The latter cases attributed conduct with reference to operational control and authorization, regardless of whether those powers were conduct relevant; Jaloud, on this reading, would attribute based on full command, equally regardless of its conduct relevance. If Behrami and H.N. over-attribute to the lead entity, this reading of Jaloud would over-attribute to contributor states.

What this reading of Jaloud gets right about article 6 is that the levers of preventive control

\footnotetext{
${ }^{109}$ Cf. Al-Skeini, supra note 12, paras. 149-150 (establishing the "jurisdictional links" necessary to trigger the investigative duties of the United Kingdom by showing that the deaths were "caused by the acts of British soldiers during the course of or contiguous to security operations" and "when British soldiers carried out a patrol in the vicinity of the applicant's home and joined in the fatal exchange of fire.")

${ }^{110}$ Cf. Al-Skeini, supra note 12, paras. 97-100.

${ }^{111}$ Cf. Sari, supra note 35, Part III.

112 Ibid., Part V.1 (noting an interpretation of Jaloud that would hold "that full command is a sufficient reason to attribute wrongful conduct to a State.")

${ }^{113}$ Moreover, since states rarely cede full command, it would entail universal attribution of CME conduct to troop contributors. See e.g. NATO Glossary of Terms and Definitions, (AAP-06) 2013, p.2-F-7; Sari, supra note 54, p.79.
} 
that make up "full command" matter to whether it makes sense to speak of seconded organs acting on the recipient's "authority." What it gets wrong is to suggest that seconded organs only act on recipients' authority when the latter holds the levers of full command. A better reflection of the complexity of authority and control here would develop DARSIWA article 6 in light of the DARIO article 7 approach, evaluating bifocally whether CME troops acted on the authority of the sending or the receiving state (or both), as determined by which of those entities had the levers of authority and control relevant to determining the troops' conduct.

Jaloud can in fact be read in that alternative way. The Dutch troops were not instructed by UK command to shoot in the conditions that led to Jaloud's death; quite the contrary, the shooting arguably exceeded what the UK had authorized. ${ }^{114}$ Since the levers of control entailed by full command are clearly relevant to preventing conduct that violates orders or abuses discretion, the attribution of the shooting to the Netherlands was entirely appropriate on a preventive interpretation of effective control. ${ }^{115}$ Although relying on reasoning that is not explicit in the judgment, this alternative reading makes sense of Jaloud's reliance on Dutch full command, without implying that it ought to guide attribution irrespective of its relevance to the impugned conduct. It would instantiate a bifocal, conduct-specific interpretation of DARSIWA article 6 or could be rooted in the DARIO article 7-inspired interpretation of DARSIWA article 8 advocated in Part B.

A clearer step backwards was taken by the Court of Appeal in England and Wales in Mohammed v. Secretary of Defence, which involved the liberty claim of a suspected Taliban commander, detained without charge for 110 days by UK troops acting as part of the UNauthorized and NATO-run International Security and Assistance Force in Afghanistan (ISAF). ${ }^{116}$ The UK argued that Mohamed's detention was attributable exclusively to the UN. ${ }^{117}$ It lost, but the Court accepted much of its argument. Repeating Al-Jedda's equivocation (in the opposite direction), the Court found that the Security Council had both 'effective control' and "ultimate authority and control" over ISAF, because ISAF was created and authorized by the Security Council, with NATO exercising operational control pursuant to Security Council authority. ${ }^{118}$

\footnotetext{
114 Jaloud, supra note 12, para. 59

${ }^{115}$ Dannenbaum, 'Translating,' supra note 46, pp.158-170.

${ }^{116}$ Mohamed, supra note 12.

117 Ibid. para. 50.

${ }^{118}$ Ibid. para 65.
} 
Consequently, the Court held, "the actions of ISAF are attributable to the United Nations."119

The dubious invocation of 'effective control' notwithstanding, it is difficult to interpret this as anything other than a revival of Behrami. Emphasizing the fact that ISAF was created by the Security Council authorization, rather than being authorized after having been deployed, the Court distinguished the facts of Al-Jedda on the same grounds that Al-Jedda had distinguished the facts of Behrami. ${ }^{120}$ The implication is that Al-Jedda rested on that factual distinction, not the putative doctrinal shift discussed above.

The Court's presumption, then, was that ISAF conduct was attributable to the UN. However, Behrami recognized the possibility of rebutting that presumption when another entity usurps control. ${ }^{121}$ The Court found that precisely that occurred in Afghanistan. NATO required authorization from ISAF Command for any detention longer than 96 hours. ${ }^{122}$ The UK, however, used a "national policy caveat" to allow for longer detention when authorized by the Ministry of Defence, relegating ISAF to the role of "liaison and coordination" in such cases. ${ }^{123}$ Although ISAF Command did not actively object to this, ISAF leaders were not invited by the UK to authorize the policy or its application, which the UK considered "sovereign business." these extraordinary conditions, the Court attributed Mohammed's detention exclusively to the $\mathrm{UK}^{125}$

After the progress of Al-Jedda and the Dutch cases, Mohammed's reversion to Behrami's lead organization presumption and Jaloud's arguable shift to a troop contributor presumption suggest a deep ambivalence regarding the right approach to CME attribution.

\section{Themes in CME Attribution and Future Directions}

Despite that doctrinal ambiguity, two trajectories are worthy of note. First, conduct-specific attribution determinations are on the rise, even if (as in Mohamed) they occasionally involve rebutting a presumptive attributive link. Second, dual attribution has become a litigation enabler, rather than an obstacle. The progressive Mothers of Srebrenica frame remains the right way

\footnotetext{
${ }^{119}$ Ibid. para 65.

${ }^{120} \mathrm{Ibid}$. para 65. Cf. Al-Jedda, supra note 4, paras. 80-84.

${ }^{121}$ Behrami, supra note 42, paras. 135-139.

${ }^{122}$ Mohamed, supra note 12, paras. 9, 51, 68.

${ }^{123}$ Ibid. para. 68.

${ }^{124}$ Ibid. para. 68.

${ }^{125}$ Ibid. paras. 69, 72 .
} 
forward, but there are open questions regarding the status of illegal cooperative enterprises, liability attribution, and the complicity of enterprise members not attributed with conduct.

\section{The Rise of Conduct Specificity}

Behrami and H.N. articulated presumptive schemes of attribution for CME conduct; in neither case were those presumptions rebutted. Since then, however, conduct-specific attribution has dominated. In the Dutch cases and, arguably, in Al-Jedda, the courts' analyses were bifocally conduct-specific all the way down; the question was which entity controlled the conduct, not whether the control of one displaced the presumptive responsibility of the other.

Although Mohammed returned to a scheme of presumptive attribution, that presumption was rebutted by the UK's national policy caveat and conduct-specific control. Jaloud is unclear on this issue, but the reconstruction offered above would define even its analysis in conductspecific terms. As courts become more comfortable with the need to evaluate the specific links between CME participants and the impugned conduct in all cases, the core value of an enterprise presumption-its simplification of the analysis and clarification of the target of claimsdiminishes considerably.

\section{The Theoretical Possibility of Dual Attribution}

A second theme has been courts' growing recognition of the theoretical possibility of dual attribution combined with their failure to actually attribute CME wrongs to more than one entity. This spotlights a peculiar role for the concept. If it were necessary to perform a complete attribution analysis in any particular case, a broader scheme of dual attribution could disempower courts by triggering jurisdictional obstacles and the indispensable third party doctrine. ${ }^{126}$ However, an expanded dual attribution doctrine in a context in which the full attribution analysis need not be performed (but exists in theory), has empowered courts by playing a role that precludes its own elaboration in practice. ${ }^{127}$ Crucial in facilitating this has been the growing openness to dual attribution via different attributive links (or different levers of control), such that - in contrast to Hess - attribution to one state or organization implies nothing about

\footnotetext{
${ }^{126}$ On international courts, see supra n 39. On domestic courts, see Yoram Dinstein, 'Par in Parem Non Habet Imperium,' (1966) 1 Israeli Law Review pp. 407-420.

${ }^{127}$ When attribution to a third party not involved in the litigation has been considered, it has, thus far (perhaps not coincidentally), been rejected. Al-Jedda, supra note 4, paras 80-84.
} 
attribution to the other(s). ${ }^{128}$

This may not be an indefinite equilibrium. The ICJ has wavered on the application of its own indispensable third party doctrine and the ECtHR has grown increasingly comfortable with issuing judgments that have all but ruled on the illegality of US conduct in the CIA black site and extraordinary rendition program. ${ }^{129}$ That may portend a willingness to attribute CME conduct even in cases in which dual attribution to another state or organization is a necessary implication.

\section{The Path Forward}

How often and in what circumstances dual attribution will be applicable going forward will depend on the model of attribution that emerges from the existing case law. In my view, the bifocal, preventive interpretation of effective control ought to be the leading candidate. It is at the core of the Dutch cases, and consistent with Al-Jedda and Jaloud (on at least one interpretation). It is also compatible with the outcome, if not the reasoning, of Mohammed, since the UK directed the detention, the detention contravened NATO rules, and the UK controlled obedience generation. Moreover, it reflects the principles underpinning the DARIO. ${ }^{130}$

Despite the textual distinctions between the DARIO and the DARSIWA, normative consistency militates in favor of harmonization around this norm. If this cannot be achieved through a progressive interpretation of DARSIWA articles 6 and 8, the broader jurisprudence developing around DARIO article 7 may provide the grounds for a universal custom applicable to both state- and organization-led CMEs.

The preventive 'effective control' framework is desirable in its instantiation of the core principle that the assertion of public power entails preventive responsibility regarding global wrongs, and in its affirmation of the fundamental value of institutionally thick international

\footnotetext{
${ }^{128}$ See Nuhanović Appellate Judgment, supra note 64, para. 5.9; Mothers of Srebrenica v. Netherlands, supra note 83, para 4.45 .

${ }^{129}$ On the ICJ, see: Nauru, supra note 39, para. 55. On the ECtHR, see: El-Masri v. The Former Yugoslav Republic of Macedonia, 13 December 2012, European Court of Human Rights, no. 39630/09, para 239; Al-Nashiri v. Poland, 24 July 2014, European Court of Human Rights, no. 28761/11, para. 516. The US is not party to the ECHR, but it is bound by the ban on torture at home and abroad. Committee Against Torture, Concluding observations on the third to fifth periodic reports of United States of America (November, 2014) para 10; White House Office of the Press Secretary, Statement by NSC Spokesperson Bernadette Meehan on the U.S. Presentation to the Committee Against Torture (12 November, 2014).

${ }^{130}$ The ILC termed this a 'wide meaning' of 'effective control,' without specifying whether it disagreed. DARIO with Commentaries, supra note 14, p.93, fn.129. There are good reasons to consider it the optimal interpretation of article 7. Dannenbaum, 'Killings at Srebrenica,' supra note 22, p. 721.
} 
cooperation. ${ }^{131}$ Unlike frameworks that rely on enterprise presumptions, it does not impute conduct to states or organizations whose only way of avoiding that attribution would be to avoid participation in the enterprise, to refuse to compromise on the allocation of enterprise control, or to contravene command structures in the field. ${ }^{132}$

Assuming the doctrine develops stably in that direction, a series of additional questions are likely to arise. First, should the attribution framework for CME wrongs depend on the lawfulness of the cooperative venture? On the one hand, neither the DARIO nor the DARSIWA suggests the possibility of divergent tests for lawful and illegal ventures, and no court has considered the idea. On the other hand, if it is correct that the preventive control structure is underpinned normatively by the importance of lawful cooperation, it seems reasonable to ask whether that approach should extend to illegal ventures, or whether the latter should trigger a broader attribution doctrine, analogous to joint criminal enterprise. Second, as dual attribution becomes more common, a clear and explicit framework for apportioning liability will become essential. ${ }^{133}$ Finally, vicarious responsibility warrants greater attention. What forms of responsibility vis-à-vis wrongful enterprise conduct attach to CME participants not attributed with the wrong?

\section{E. Conclusion}

The rapidly expanding jurisprudence on cooperative military ventures has yet to coalesce around a single normative framework. The role of the DARIO and DARSIWA in that realm has been decidedly mixed, perhaps predictably given the inconsistency between the two codes. The most hopeful developments have come in the Netherlands, with the elaboration of a bifocal, preventive interpretation of DARIO article 7. However, whether that framework will resonate elsewhere is uncertain.

In all of this, the concept of dual attribution has played an odd role. It has been affirmed repeatedly in theory, but the primary value of its theoretical possibility has been in empowering courts to hear cases they might otherwise have avoided, while failing actually to attribute conduct to two or more entities. If courts were to start to apply dual attribution, new questions would arise. What would such a finding mean for the allocation of reparative responsibilities?

\footnotetext{
${ }^{131}$ Dannenbaum, 'Public Power,' supra note 10.

${ }^{132}$ Id. pp. $\mathrm{xx}-\mathrm{xx}$.

${ }^{133}$ On the right to reparation, see Ian Brownlie, The Rule of Law in International Affairs (Martinus Nijhoff, 1998) pp. 79-80.
} 
How would sharing public responsibility affect the domestic political impact of such a ruling? Ought both states and international organizations submit to a single in-theater process, such as an expanded version of the never-delivered UN standing claims commission? ${ }^{134}$

${ }^{134}$ Draft Model Status of Forces Agreement for Peace-keeping Operations (A/45/594) Annex (9 October 1990) art 51. 